\title{
Thriving at work: Toward its measurement, construct validation, and theoretical refinement
}

\author{
CHRISTINE PORATH ${ }^{1, \dagger}$, GRETCHEN SPREITZER $^{2, \dagger *}$, CRISTINA GIBSON $^{3}$ AND \\ FLANNERY G. GARNETT ${ }^{4}$ \\ ${ }^{1}$ Management and Organizations, Georgetown University, Washington, D.C., U.S.A. \\ ${ }^{2}$ Management and Organizations, University of Michigan, Ann Arbor, Michigan, U.S.A. \\ ${ }^{3}$ Management and Organizations, University of Western Australia, Australia \\ ${ }^{4}$ Management, University of Utah, Salt Lake City, Utah, U.S.A.
}

\begin{abstract}
Summary Thriving is defined as the psychological state in which individuals experience both a sense of vitality and learning. We developed and validated a measure of the construct of thriving at work. Additionally, we theoretically refined the construct by linking it to key outcomes, such as job performance, and by examining its contextual embeddedness. In Study 1, we conducted second-order confirmatory factor analyses in two samples, demonstrating initial support for the two-dimensional structure of thriving. We provided evidence for the convergent and discriminant validity of thriving in relation to theoretically related constructs, such as positive and negative affects, learning and performance goal orientations, proactive personality, and core self-evaluations. In Study 2, across two different samples, we further assessed construct validity by establishing a relationship between thriving and career development initiative, burnout, health, and individual job performance, explaining significant variance beyond traditional attitudinal predictors, such as job satisfaction and organizational commitment. Finally, in Study 3, we focused on understanding the contextual embeddedness of thriving. We found differences in reports of thriving across two points in time, when substantial changes are occurring in peoples' work lives and across contexts (i.e., work and non-work). Implications for theory and practice, as well as directions for future research, are discussed. Copyright () 2011 John Wiley \& Sons, Ltd.
\end{abstract}

Keywords: thriving; vitality; learning; construct validation; performance; burnout

Thriving is a psychological state composed of the joint experience of vitality and learning (Spreitzer, Sutcliffe, Dutton, Sonenshein, \& Grant, 2005). People who are thriving experience growth and momentum marked by both a sense of feeling energized and alive (vitality) and a sense that they are continually improving and getting better at what they do (learning). Spreitzer et al. (2005) developed a socially embedded model of thriving at work, in which they defined thriving, distinguished it from related constructs, and explained how the experience of thriving is shaped by the context in which individuals are embedded. In this work, thriving is conceptualized as an adaptive function because it provides an internal cue, helping individuals to assess their forward progress. Spreitzer et al. suggested that thriving matters because it enhances the health and personal development of employees. We argue that thriving is particularly important in today's work environment, as individuals must learn to navigate protean careers (Hall, 1998) and to sustain their performance, health, and well-being over time (Pfeffer, 2010) especially as recovery opportunities become more scarce (Sonnentag \& Fritz, 2007). We posit that thriving is a means to mitigate

*Correspondence to: Gretchen Spreitzer, Management and Organizations, University of Michigan, Ann Arbor, Michigan 48109, U.S.A. E-mail: spreitze@umich.edu

${ }^{\dagger}$ Christine Porath and Gretchen Spreitzer share first authorship. Their names are in alphabetical order. 
burnout (Maslach, 2003). Thus, thriving not only has the potential to enhance a variety of crucial outcomes for individuals, such as career development initiative and general health, but can also benefit the organization through increased performance and lower health care costs.

To examine these ideas empirically in a programmatic way, we extended the theoretical work of Spreitzer et al. (2005) by the following: (i) crafting and validating a measure; (ii) examining its construct validity with respect to key outcomes; and (iii) exploring its contextual properties through the investigation of thriving at different points in time and across contexts.

The construct validation of thriving is a valuable contribution to the positive psychology literature; as highlighted by Seligman and Csikszentmihalyi's (2000, p. 5) argument, we need "a scientific understanding and effective interventions to build thriving in individuals, families, and communities." Our construct validation also contributes to the growing positive organizational behavior (POB) literature (Luthans, 2002; Luthans \& Youssef, 2007), which places emphasis on positive states such as psychological capital (composed of hope, optimism, resilience, and self-efficacy dimensions; Luthans, Youssef \& Avolio, 2007; Luthans, Avolio, Avey, \& Norman, 2007). Finally, the present work contributes to positive organizational scholarship (POS; Cameron, Dutton, \& Quinn, 2003), which focuses on positive deviance as a mechanism enabling both individuals and their organizations to thrive.

In the next section, we briefly review the literature. We then present three studies, employing five different samples, to address these objectives. We conclude with a discussion of the contributions, limitations, and directions for future research.

\section{Literature Review and Definition of Thriving}

Interest in thriving dates back to work by Maslow (1943), Rogers (1961), and Alderfer (1972). When psychologically thriving, individuals are not merely surviving (Saakvitne, Tennen, \& Affleck, 1998) or getting by (Benson \& Scales, 2009) but rather are growing (Calhoun \& Tedeschi, 1998; Carver, 1998; Ickovics \& Park, 1998; Joseph \& Linley, 2008) or on an upward trajectory (Hall et al., 2009; Thomas \& Hall, 2008).

Spreitzer et al. (2005) advanced a two-dimensional conceptualization of thriving, composed of the following: (i) a feeling of vitality and (ii) a sense that one is learning or getting better. Vitality represents a sense that one is energized (Nix, Ryan, Manly, \& Deci, 1999) and has a zest for work (Miller \& Stiver, 1997). The learning dimension signifies the acquisition and application of knowledge and skills to build capability and confidence (Carver, 1998). Together, the two dimensions capture both the affective (vitality) and cognitive (learning) essence of the psychological experience of personal growth. Ryff (1989), for example, suggested that when individuals grow, they consider themselves to be expanding in ways that reflect enhanced self-knowledge and effectiveness. Likewise, Carver (1998) conceived of thriving as the psychological experience of growth in a positive capacity (i.e., a constructive or forward direction) that energizes and enlivens. Thus, the two dimensions are consistent with prior psychological research that highlights the importance of simultaneously considering the affective and cognitive foundations of human growth.

We suggest—not only in line with the foundational research on thriving (e.g., Spreitzer et al., 2005) but also because of our specific interest in organizations as an important context for thriving-that vitality and learning combine to capture the essence of thriving in a work context. Although each dimension can signify some progress toward growth and personal development at work, it is only in concert that they enhance one another to form the experience of thriving. If one is learning but feels depleted, thriving suffers. For example, consider a nurse who is learning as he or she masters new procedures and technologies but feels depleted by his or her work. He or she only experiences limited thriving because one of its components (i.e., vitality) is languishing. His or her development is stunted-he or she does not have the capacity to fully realize learning as a result of low(er) energy. Conversely, if one feels energized and alive while working but finds personal learning to be 
stagnant, again, the experience of thriving is limited. A call center worker may feel energized by satisfying customer needs but may find that the routine work provides few opportunities to learn and improve and that training and development activities are not provided. In this case, the call center worker also experiences limited thriving because this individual is energized but is not learning. Thriving represents the joint experience of a sense of vitality and learning and is most accurately conceptualized as a continuum-where people are more or less thriving at any point in time-rather than a dichotomous state of either thriving or not (Saakvitne et al., 1998).

In the first study, we demonstrate how the two dimensions of vitality and learning combine to create the higherorder construct of thriving at work and compare thriving to related constructs. In the second study, we further examine the construct validity of thriving at work by examining its relationships to theoretically related constructs in an effort to establish its distinctiveness. Finally, in the third study, we explore how thriving might be contextually embedded, specifically by examining thriving at work during a critical time point when the nature of a person's work is likely to be changing (i.e., change in job), and assess the degree to which thriving is congruent both inside and outside of work. These three studies build upon one another to provide evidence for the construct validity of thriving at work.

\section{Study 1}

In Study 1, we developed a nomological network to establish construct validity (Cronbach \& Meehl, 1955), which includes not only a theoretical framework of how the construct of interest is related to other established constructs but also an empirical framework for how that construct is measured. As part of the nomological network, we first assess the convergent and discriminant validity of thriving by empirically examining the extent to which the pattern of correlations between thriving and related constructs conform to theoretical propositions (Campbell et al., 1996; DeVellis, 2003; Judge, Erez, Bono, \& Thoresen, 2003). In the next sections, we build the case for why thriving should be correlated to positive and negative affects, learning (but not performance) goal orientation, proactive personality, and core self-evaluations.

Positive and negative affects. Positive affect (PA) and negative affect (NA) - experienced as positively and negatively valenced moods (i.e., affect experienced over time) or dispositions (i.e., relatively stable personality characteristics), respectively (Seo, Barrett, \& Bartunek, 2004)—are related to, but distinct from, thriving (Spreitzer et al., 2005). That is, neither PA nor NA is necessarily indicative of learning, growing, or moving in a forward direction. The vitality dimension, because it is a high activation manifestation of PA, should be more related to PA than to NA. Similarly, when people experience NA, we posit that they will not feel vital; they are less inclined to feel energetic and to possess a positive outlook about their growth and development. Although we expect PA and NA to be somewhat related to the vitality component of thriving given its affective component, neither captures its learning component. Accordingly, we expect that

Hypothesis 1a: Thriving is positively related to positive affect.

Hypothesis $1 b$ : Thriving is negatively related to negative affect.

Learning and performance goal orientations. Three goal orientations have been proposed in the literature: learning goal orientation, performance-prove orientation, and performance-avoid orientation (Elliot \& Harackiewicz, 1996; Vandewalle, 1997). People with a high learning goal orientation view skills as malleable (Martocchio, 1994) and focus on developing the ability to achieve future tasks (Button, Mathieu, \& Zajac, 1996; Farr, Hofmann, \& Ringenbach, 1993). In particular, employees with a learning goal orientation are more likely to pursue self-development (Farr, Hofmann, \& Ringenbach, 1993) because they are interested in increasing competency and are motivated by growth and development needs (Brockner \& Higgins, 2001). Thus, we would 
expect that those high in learning goal orientation are more likely to thrive. However, we also expect thriving to be distinct from such an orientation, given that learning goal orientation is often conceptualized as a disposition toward developing competence by acquiring new skills and mastering new situations (Dweck \& Leggett, 1988). One can have a disposition toward learning but be embedded within an environment that impedes thriving. For example, an employee may have a high learning goal orientation but work for an organization that provides little opportunity for growth.

Also, as described earlier, thriving is about more than just learning; it is about joint feelings of vitality and energy, which may be drained when the focus is entirely on acquiring new skills and mastering situations. On the other hand, we expect that thriving will not be related to the two performance orientations because they are the antithesis of learning: A performance-prove orientation involves demonstrating and validating one's competence, whereas a performance-avoid orientation focuses on avoiding negative outcomes and typically motivates processes that are detrimental to achievement outcomes because these self-protective processes interfere with task engagement (Elliot \& Harackiewicz, 1996). We expect that individuals who are focused on growing and developing at work (i.e., the learning component of thriving) will likely not possess a performance-prove or performance-avoid orientation. Those with a performance-prove orientation possess an extreme focus on achievement. Therefore, they would likely be less interested in development and growth along the way. Those with a high performance-avoid orientation are characterized with a fear of failing to achieve; as a result, they often forfeit developmental opportunities, bypassing chances to try things that spark growth if there is a chance of risk. In these ways, both of these performance goal orientations limit thriving.

Hypothesis 2: Thriving is positively related to learning goal orientation.

Hypothesis 3: Thriving is not related to performance-prove or performance-avoid goal orientation.

Proactive personality. Proactive personality, the tendency to take action to influence one's environment (Bateman \& Crant, 1993), is likely related to thriving because proactive individuals report greater intentional constructive change (Bateman \& Crant, 1993) and are more likely to pursue opportunities for self-improvement (Parker, Williams, \& Turner, 2006), including learning skills or acquiring education (Seibert, Crant, \& Kraimer, 1999). Additionally, proactive individuals are more attuned to their environments, engage in greater learning, and are apt to put themselves in positions where they are more likely to experience thriving (e.g., Crant, 1995; Porath \& Bateman, 2006). However, although we expect proactive personality to be related to thriving, there are conceptual distinctions between the two. An individual can be proactive in orientation but embedded in a work environment that impedes his or her ability to thrive. More specifically, a person may be in a position emphasizing routinization and conformity with limited opportunities for growth and development. In such a scenario, feelings of vitality would likely be reduced. Thus,

Hypothesis 4: Thriving is positively related to proactive personality.

Core self-evaluations (CSE). CSE, composed of self-esteem, locus of control, emotional stability, and generalized self-efficacy (Judge, Erez, Bono, \& Thoresen, 2003), does not focus explicitly on vitality or learning, and as such, we expect it to be theoretically and empirically distinct from thriving. However, the four specific traits comprising CSE may each be related to an individual's propensity to thrive. For instance, those with low self-esteem tend to over-generalize negative outcomes as personal failings, which, subsequently, impede their learning and vitality (Brown \& Dutton, 1995). Those high in generalized self-efficacy are more likely to engage actively in tasks because they are more confident in their potential success, and such task engagement is likely to generate vitality and to enhance possibilities for learning and, ultimately, thriving. Internal locus of control may predispose an individual to thrive, as it impacts a person's willingness to act agentically (Judge, Erez, Bono, \& Thoresen, 2002). Prior research on self-determination has shown repeatedly that autonomy at work increases feelings of vitality (Deci \& Ryan, 2000). Finally, individuals who are emotionally stable are more likely to thrive because they tend to experience 
more positive affect, and their emotional security can enhance their potential for learning, especially in new situations (Wiggins, 1996).

Hypothesis 5: Thriving is positively related to core self-evaluations.

\section{Method}

We first conducted a pilot study that focused on the generation of items to represent the dimensions of vitality and learning. We drew seven items from Ryan and Frederick's (1997) subjective vitality scale that captures the state of having energy available and ready for use. We also included an additional three items to capture the absence of vitality (see Table 1). Learning has been measured objectively with respect to improvements in performance (e.g., Reagans, Argote, \& Brooks, 2005), as a stable orientation, as an individual difference (Hackman \& Oldham, 1980), and as a set of behaviors including feedback seeking, experimentation, and discussion of errors (Edmondson, 1999; Gibson \& Vermeulen, 2003). None of these established measures, however, were appropriate to measure the learning component of thriving because we are interested in an individual's subjective experience of learning, rather than learning performance, learning as an individual difference, or learning as a specific behavior. Consequently, we developed 14 items to capture the subjective experience of learning, including both positively and negatively worded items (see Table 1). We also included a single item, "I am really thriving," to capture overall thriving.

Table 1. Pilot items.

Preliminary items to measure the vitality dimension of thriving

I feel alive and vital

I feel so alive I just want to burst

I have energy and spirit

I am looking forward to each new day

I feel energized

I feel alert and awake

I do not feel very energetic ${ }^{\mathrm{a}}$

I feel depleted ${ }^{\mathrm{a}}$

I am lethargic ${ }^{\mathrm{a}}$

I lack energy ${ }^{a}$

Preliminary items to measure the learning dimension of thriving

I am experiencing considerable personal growth

I am growing in positive ways

I have not grown much recently

I am stagnating ${ }^{\mathrm{a}}$

I enjoy seeing how my views have progressed

I continue to learn more as time goes by

I am finding new ways to develop

I am not learning ${ }^{\mathrm{a}}$

I am developing a lot as a person

I am not moving forward

I find myself learning often

I see myself continually improving

I think I am continuing to develop

I am failing to progress ${ }^{a}$

\footnotetext{
${ }^{\mathrm{a}}$ Items were reverse coded.
} 
The pilot sample consisted of 30 working adults $(55 \%$ men; mean age $=27.8$ years $)$ in a variety of occupations (e.g., consultant, engineer, administrator). Participants responded to each item by reflecting on their experiences at work, using a seven-point scale $(1=$ strongly disagree to $7=$ strongly agree $)$. In addition, we asked for qualitative feedback about whether any items were confusing, difficult to answer, or repetitive. We retained items for further analysis if they correlated with the overall thriving item at a level of at least .40 as well as if respondents raised no questions or concerns about the item, resulting in five items that represent the vitality component of thriving (inter item correlations (Pearson's $r$ ) $=.40-.77$ ) and five items that capture the learning component (inter item correlations (Pearson's $r$ ) $=.54-.78$ ).

Building on this pilot study, we then set out to establish the validity of the thriving construct by examining its factor structure, reliability, and the degree to which thriving is similar to and distinct from related constructs in two relatively diverse samples.

\section{Samples}

Young adults sample. One hundred seventy-five undergraduate students (63\% men) enrolled in a senior-level business course at a large Western university in the USA comprised the first sample. Ages of the participants ranged from 18 to 34 years, with a mean age of 21 years. In the sample, $37 \%$ were currently working, and the remaining $63 \%$ reflected on their last employment. Participants reported working an average of 25 hours a week. Work experience represented a wide range of industries, including advertising/marketing/public relations, entertainment, education, community service, retail/sales, hospitality/restaurant, manufacturing, and others.

Young professionals sample. Four hundred ten young professionals in a variety of industries (e.g., consulting, financial services, health care, manufacturing, non-profits) comprised the second sample. We collected the data using an online assessment completed approximately one month prior to starting a Master of Business Administration degree (MBA) program at a large Midwestern university. Three hundred twenty-four completed the survey instrument (response rate $=79 \%)$, and respondents $(66 \%$ men; mean age $=28.3$ years; average of 5.6 years of work experience) did not differ significantly from non-respondents on demographics. We provided feedback to individual participants for their own development and assured each of them that their responses would remain confidential.

\section{Measures}

Participants responded to the 10-item thriving scale created in the pilot study. We first computed a composite score for the vitality and for the learning components, which was the mean of the five items that captured vitality and learning, respectively. We asked respondents to assess their level of vitality and learning "in relation to their work," rather than "more generally," which would be more consistent with a dispositional measure.

To assess convergent and discriminant validity in the first sample (i.e., young adults), respondents completed measures of PA and NA, learning and performance goal orientations, and proactive personality. In this sample, we measured PA and NA with the 10 positive items $(\alpha=.85)$ and 10 negative items $(\alpha=.83)$, respectively, from the PA and NA schedule (Watson, Clark, \& Tellegen, 1988). We asked participants the extent to which they tended to feel these positive (e.g., proud) and negative (e.g., upset) emotions $(1=$ not at all; $7=$ extremely). We measured learning and performance goal orientations using VandeWalle, Cron, and Slocum's (2001) scales, using a sevenpoint scale $(1=$ strongly disagree; $7=$ strongly agree $)$. We measured learning goal orientation $(\alpha=.81)$ with four items (e.g., "For me, development of my work ability is important enough to take risks"). The performance-prove goal orientation measure $(\alpha=.70)$ included four items (e.g., "It's important for me to prove that I am better than others"), and the performance-avoid goal orientation scale $(\alpha=.77)$ contained five items (e.g., "I prefer to avoid situations in classes where I could risk performing poorly"). We measured proactive personality $(\alpha=.74)$ with five items (e.g., "I am always looking for better ways to do things") from Bateman and Crant (1993) (1= strongly disagree; 7 = strongly agree). 
In the young professionals sample, respondents completed measures of core self-evaluations and PA. We assessed core self-evaluations ( $\alpha=.81$ ) with 12 items (e.g., "I am confident I get the success I deserve in life"), from Judge and colleagues' (2003) measure, using a five-point scale $(1=$ strongly disagree to $5=$ strongly agree $)$. We assessed PA $(\alpha=.82)$ with Fredrickson, Tugade, Waugh, and Larkin's (2003) 10-item scale of positive emotions. Participants responded using a six-point scale $(1=$ never to $6=$ every day) regarding their affective experiences over the past month, which were presented in trios of related positive emotions (e.g., "hopeful, optimistic, encouraged" and "glad, happy, joyful").

\section{Results}

\section{Reliability and factor structure}

In both samples, we conducted a second-order confirmatory factor analysis (CFA) using LISREL 8 (Jöreskog \& Sörbom, 1993). We specified the five vitality and five learning items to load on separate latent vitality and learning factors, respectively. We then specified the latent vitality and learning factors to load onto a second-order latent factor representing the higher-order construct of thriving. Because there are just two first-order factors, the model is under-identified (identification requires at least three first-order factors). To reduce the number of estimate parameters so that the model could be identified, we set the coefficients of the first-order loadings to be equal (personal communications, J. Edwards \& R. Bagozzi, 7 November 2007). We assessed model fit with the chisquared statistic $\left(\chi^{2}\right)$ and fit indices, including the root mean square residual, root mean square error of approximation (RMSEA), relative fit index, and comparative fit index.

Across both examples, the second-order factor structure achieved, with little exception, an acceptable fit to the data (see Tables 2 and 3 for factor loadings and fit statistics); results indicate that our two factor (i.e., learning and vitality) conceptualization of thriving provides a good fit to the data. The chi-square and RMSEA are exceptions to our overall findings, with some values exceeding the .05 level of significance and the .05 fixed cutoff, respectively.

Table 2. Confirmatory factor analysis results across two samples.

Factor loadings

Items

"At work, ..."

Sample 1

Sample 2

Learning latent factor

... I find myself learning often

... I continue to learn more as time goes by

... I see myself continually improving

... I am not learning (R)

... I am developing a lot as a person

$\begin{array}{ll}.62 & .77 \\ .73 & .72 \\ .83 & .73 \\ .72 & .59 \\ .88 & .57\end{array}$

Vitality latent factor

... I feel alive and vital

... I have energy and spirit

... I do not feel very energetic (R)

... I feel alert and awake

... I am looking forward to each new day

Learning-thriving second-order loading

Vitality-thriving second-order loading

Correlation between learning and vitality 
Table 3. Confirmatory factor analysis (CFA) results for thriving for two samples.

\begin{tabular}{lcccc}
\hline Fit statistic & Second-order CFA & Single factor & Second-order CFA & Single factor \\
\cline { 2 - 5 } & Sample 1 & Sample 1 & Sample 2 & Sample 2 \\
\hline Degrees of freedom $(d f)$ & 34 & 35 & 34 & 35 \\
Chi-square $\left(\chi^{2}\right)$ & 67.66 & 133.68 & 122.34 & $(p=.001)$ \\
& $(p=.001)$ & $(p=.001)$ & 241.69 & $(p=.00)$ \\
Difference in $\chi^{2}$ & 66.02 & & $(p=.001)$ & .08 \\
& $d f=1$ & .09 & .15 \\
Root mean square residual & $(p=.001)$ & .19 & .97 \\
Root mean square error of approximation & .06 & .95 & .14 \\
Comparative fit index & .09 & .91 & .94 \\
Relative fit index & .98 & & .87 \\
\hline
\end{tabular}

Experts suggest that researchers should be cautious about a fixed cutoff point for RMSEA, indicating that it should depend on model specifications, degrees of freedom, and sample size (Chen, Curran, Bolen, Kirby, \& Paxton, 2008). Given that the other fit statistics are well within the acceptable range, we further assessed an alternative, single-factor model, in which all items were specified to load on a single factor meant to represent the thriving construct. By using a chi-squared difference test, the fit of the original, multidimensional model was significantly better than the single-factor model (see Table 3 for comparative fit statistics).

\section{Construct validity}

We presented means, standard deviations, and correlations in Tables 4 (young adults sample) and 5 (young professionals sample). We examined the convergent and discriminant validity of thriving with respect to the theoretically related constructs mentioned earlier, with CFAs conducted to demonstrate the distinctiveness of thriving in relation to each construct. In the young adults sample, we found a significant improvement in fit when we modeled thriving as distinct from PA and NA than when we modeled PA or NA as an additional latent factor on thriving (i.e., set to load on the same factor as thriving) (PA: $\Delta \chi^{2}(1)=50.80, p<.01$; NA: $\Delta \chi^{2}(1)=101.67$, $p<.001)$. The correlations between thriving and PA and NA are $.49(p<.001)$ and $-.31(p<.01)$, respectively, both of which are different from one. In another model, we found a significant improvement in fit for thriving as distinct from learning goal orientation $\left(\Delta \chi^{2}(1)=207.76, p<.01\right)$ and from proactive personality $\left(\Delta \chi^{2}(1)=7.14, p<.05\right)$. The correlations between thriving and learning goal orientation $(r=.37, p<.01)$, performance-prove orientation $(r=.20$, not significant $(\mathrm{ns}))$, performance-avoid orientation $(r=-.04, \mathrm{~ns})$, and proactive personality $(r=.56, p<.01)$ are also different than one. Importantly, the two performance goal orientations are not significantly related to thriving, as we expected. Overall, these results provide support for our expectations of the relationships between thriving and other theoretically related constructs and garner evidence of convergent and discriminant validity.

In the young professionals sample, we, once again, conducted CFAs to demonstrate convergent and discriminant validity. In modeling the thriving and positive emotion items, we found a significant improvement in fit when we modeled thriving as distinct from positive emotions than when we specified positive emotions as an additional latent factor of thriving $\left(\Delta \chi^{2}(1)=35.42, p<.01\right)$. Likewise, in another model examining the thriving and CSE items, we found a significant improvement in fit when we modeled thriving as distinct from CSE than when we specified CSE as an additional latent factor on thriving $\left(\Delta \chi^{2}(1)=53.21, p<.01\right)$. The correlations between thriving and CSE $(r=.46, p<.01)$ and positive emotions $(r=.52, p<.01)$ are both significantly less than one, providing further evidence of convergent and discriminant validity.

Study 1 provides initial evidence for the convergent and discriminant validity of thriving in relation to theoretically related constructs. That is, although these related constructs are significantly correlated as hypothesized, none is so closely related as to raise questions about the distinctiveness of the thriving measure. 


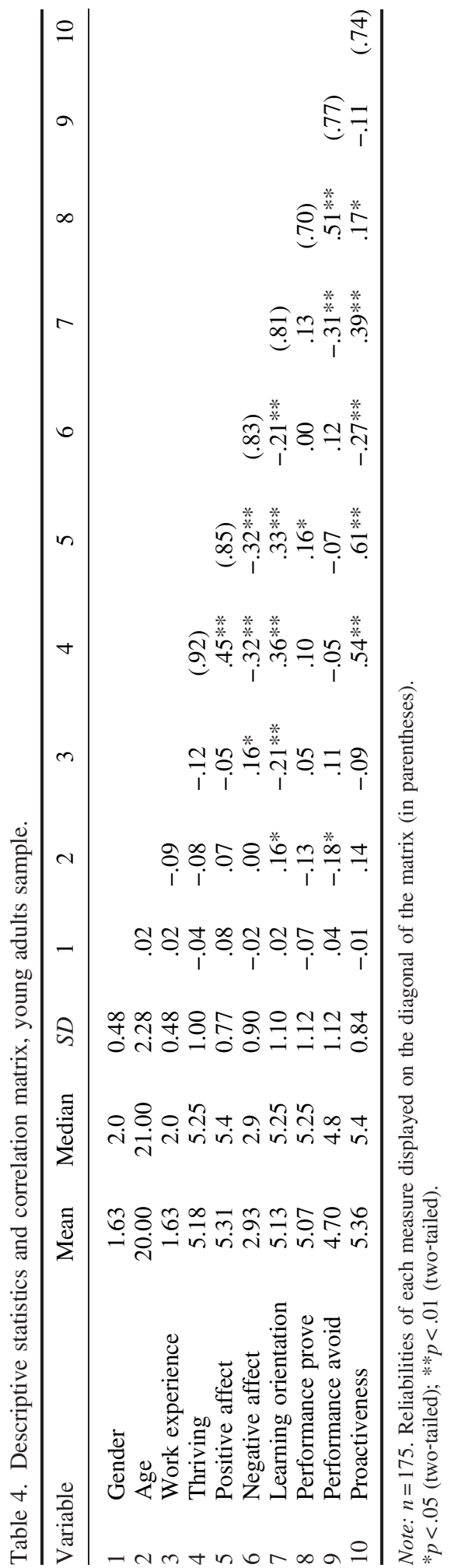


Table 5. Descriptive statistics and correlation matrix, young professionals sample.

\begin{tabular}{|c|c|c|c|c|c|c|c|c|c|c|}
\hline \multicolumn{2}{|c|}{ Variable } & \multirow{2}{*}{$\begin{array}{r}\text { Mean } \\
1.66\end{array}$} & \multirow{2}{*}{$\frac{\text { Median }}{2.00}$} & \multirow{2}{*}{$\frac{S D}{0.47}$} & \multirow[t]{2}{*}{1} & \multirow[t]{2}{*}{2} & \multirow[t]{2}{*}{3} & \multirow[t]{2}{*}{4} & \multirow[t]{2}{*}{5} & \\
\hline 1 & Gender & & & & & & & & & \\
\hline 2 & Age & 28.30 & 28.00 & 2.87 & .09 & & & & & \\
\hline 3 & Work experience & 5.55 & 5.00 & 2.43 & $.14 * *$ & $.81 * * *$ & & & & \\
\hline 4 & Thriving & 5.96 & 6.10 & 0.78 & $-.16 * *$ & -.03 & -.06 & $(.88)$ & & \\
\hline 5 & Core self-evaluations & 3.83 & 3.80 & 0.52 & .05 & -.01 & .04 & $.46 * *$ & $(.81)$ & \\
\hline 6 & Positive emotions & 4.32 & 4.40 & 0.65 & .01 & $-.14 *$ & -.10 & $.52 * *$ & $.46^{* *}$ & $(.82)$ \\
\hline
\end{tabular}

Note: $n=342$. Reliabilities of each measure displayed on the diagonal of the matrix (in parentheses). $* p<.05$ (two-tailed); $* * p<.01 ; * * * p<.001$.

Despite the first step toward construct validation demonstrated in Study 1, one might raise the question of why measures other than self-reports were not employed to assess convergent and discriminant validity. We have two reasons. First, thriving is conceptualized as an internal gauge of a sense of growth and development, which we argue is best measured through self-report. Because the related constructs are states and traits, they too are most appropriately assessed using self-report measures. We expect that using self-reports of both thriving and the related constructs provides a more conservative test of the hypothesized relationships because construct differentiation should be more difficult because of the potential influence of common method bias. Our use of two different samples provides more confidence in our results. In our next study, we examine why thriving at work may matter.

\section{Study 2}

We gather further evidence of the construct validity of thriving by assessing its relationships with career development initiative, burnout, health, and job-related performance. According to the earlier conceptual work, thriving potentially acts as an internal gauge used by individuals in the pursuit of goal attainment and personal effectiveness (Spreitzer et al., 2005, p. 537). For example, how energized a person feels (i.e., vitality) and how much they are growing and developing (i.e., learning) in their work may signal whether adjustments are necessary; making such adjustments, in turn, enables career development initiative, helps avoid burnout, and increases performance (Kanfer, 1990; Tsui \& Ashford, 1994; Wrzesniewski \& Dutton, 2001). Paying attention to an internal gauge, such as thriving, is particularly helpful for an individual's self-regulation of personal development, burnout, and performance, because others, such as managers and co-workers, may have a more difficult time evaluating the extent to which work is depleting for that individual. Assessing an individual's level of thriving might be especially difficult, given the propensity for people to impression manage while at work. So whereas individuals can adapt to changes using external cues such as goal achievement, feedback, and rewards or punishment (e.g., Porath \& Bateman, 2006), people can also adjust by tracking their psychological experience of thriving (Spreitzer et al., 2005).

Burnout. Burnout refers to cynicism and emotional exhaustion (Maslach \& Leiter, 1997). Monitoring levels of vitality and learning enables people to make corrective adjustments, such as recovery activities, to reduce the potential for burnout (Sonnentag \& Fritz, 2007). The sense of growth and momentum inherent in thriving may counteract cynicism, associated with burnout, because people feel like they are making progress and improving at their work (Lee \& Ashforth, 1990). In particular, the learning component of thriving fuels feelings of competence (Deci \& Ryan, 2000; Ryan \& Deci, 2000) and enables efficacy (Bandura, 2001), counteracting feelings of diminished accomplishment, which is sometimes considered a third dimension of burnout (Maslach \& Leiter, 
1997). When learning is combined with the vitality component of thriving-providing individuals with energy to engage in restorative behaviors (Sonnentag \& Fritz, 2007)—avoidance of burnout is particularly likely. By paying attention to bodily cues that help assess decrements in energy, individuals can make corrective changes in the moment and ward off potential exhaustion.

Hypothesis 6: Thriving is negatively related to burnout.

Career development initiative. Career development initiative, or a proactive approach to developing one's career to enable growth over time, includes activities such as obtaining the necessary skills for career progression, setting career goals, and seeking out career development opportunities (Ashford \& Black, 1996; Seibert et al., 1999). When people experience a sense that they are growing and moving in a forward direction, they yearn to continue that momentum with respect to their career development. More specifically, when individuals are thriving - with the sense that they are making progress and getting better through learning at work- they are likely to take the initiative to seek out more opportunities to acquire knowledge and skills helpful for developing their career. When combined with vitality, individuals have the fuel they need to set goals, seek out career opportunities, and develop needed skills and abilities.

Hypothesis 7: Thriving is positively related to career development initiative.

Performance. Consistent with Griffin, Neal, and Parker's (2007) performance proficiency, we conceptualize performance as the overall effectiveness in meeting expectations at work (Campbell, Ford, Rumsey, \& Pulakos, 1990), including the quality, quantity, and accuracy of products created, the level of service provided and, in the case of managers who are expected to lead those who report to them, leadership effectiveness. With thriving used as an internal gauge for self-regulation, individuals behave agentically and proactively by taking responsibility and the initiative to control their destiny, respectively, which can, in turn, enhance performance (Grant \& Ashford, 2007). Because agentic behaviors produce resources that fuel individual behavior (Hobfoll, 2002), thriving individuals produce resources endogenously, such as new knowledge, more meaning, and stronger relationships, in doing their work (Spreitzer et al., 2005). Particularly when combined with vitality, this resource creation is sustained, leading to better performance (Bruch \& Ghoshal, 2003; Marks, 1977). Fredrickson's (2001) broaden and build theory suggests that this cycle is likely the case because of positive feelings, such as vitality, build social, psychological, and physical resources that are crucial to performance. Additionally, the learning inherent in thriving also contributes to better performance, whether for individuals, for those working in teams (e.g., Gibson \& Vermeulen, 2003; Porath \& Bateman, 2006; Zellmer-Bruhn \& Gibson, 2006), or for those whose primary responsibility is to lead others.

Hypothesis 8: Thriving is positively related to individual job performance.

Health. Spreitzer and colleagues (2005) suggested that although individual job performance is clearly important in organizational contexts, thriving at work is also meaningfully associated with positive health. People with a sense of vitality, for instance, are much less likely to feel worried, depressed, or upset and are more likely to be mentally healthy (Keyes, 2002). Positive experiences such as vitality enable individuals to be more physiologically resilient to stressful situations (Tugade, Fredrickson, \& Feldman Barrett, 2004). In addition to vitality, a sense of learning contributes to positive physical health and mental well-being. For example, Ettner and Grzywacz (2001) found that employees who reported more learning at work were more likely to report that work affected their mental and physical health positively. A study by Alfredsson, Spetz, and Theorell (1985) concluded that employees with fewer possibilities to learn had a greater probability of being hospitalized for heart attacks. Thus, we expect that people who experience thriving at work will enjoy better health.

Hypothesis 9: Thriving is positively related to health. 


\section{Method}

\section{Samples}

In an effort to enhance generalizability, we examined our hypotheses using three diverse samples: a physical facilities sample, composed of employees primarily performing manual labor; a multicompany, professional sample from six different organizations across a variety of industries; and a sample of executive MBAs (EMBAs), consisting of managers completing the final course of their program.

Physical facilities sample. Two hundred seventy-six employees and their supervisors $(N=316 ; 75 \%$ men; average age $=43.0$ years; average work week $=39.9$ hours) at the physical facilities division of a large Midwestern university completed surveys on site during monthly unit meetings. We sampled employees across departments (construction services, facilities maintenance, building services, grounds management, and utilities and plant engineering). We assessed thriving and relevant controls in an initial survey and then six weeks later, assessed career development initiative and job performance. We assessed thriving using our 10 -item scale, measured on a five-point scale $(1=$ strongly disagree, $5=$ strongly agree $)$. At Time 2 , we assessed our dependent variables, both by employee's immediate supervisor, who is responsible for completing the employee's performance appraisal. We evaluated career development initiative $(\alpha=.94)$, the extent to which individuals engaged in a proactive approach to their careers (e.g., taking advantage of training acquiring new skills), using four items from Welbourne, Johnson, and Erez (1998). We obtained this measure for 230 of the 276 employees (83.3\%). We evaluated individual job performance $(\alpha=.88)$ using four items (quality, quantity, accuracy, and service), also from Welbourne et al. (1998). Participants responded to all items on a five-point scale (1=needs much improvement, $5=$ excellent $)$.

We included controls for age and gender, which may affect performance (Hoffman, Blair, Meriac, \& Woehr, 2007), and also job satisfaction and organizational commitment. Our goal here in including job satisfaction and organizational commitment is to show that thriving has an independent effect on outcomes such as career development initiative and job performance, above and beyond traditional attitudinal predictors of performance. We measured job satisfaction $(\alpha=.93)$ with three self-report items (e.g., "Overall, I am satisfied with working here") adapted from Spector (1985) and organizational commitment $(\alpha=.91)$ with five self-report items (e.g., "I feel a high level of loyalty to this organization") from Mowday, Steers, and Porter (1979). Participants responded to all items using a five-point scale $(1=$ strongly disagree, $5=$ strongly agree $)$.

Multicompany sample. To extend our assessment beyond a single organization and industry context, a random sample of employees working in six large organizations stratified by level (individual contributor, middle manager, senior manager, senior executive) completed an online assessment of thriving and burnout. We selected the six companies to represent a diverse set of industries, covering those that were fast growing (maritime, technology/computer services), stagnating (utility), and undergoing upheaval (pharmaceuticals, health care). We surveyed 50-100 employees across the four levels in these organizations, ranging from individual contributors to senior executives. In return, we provided an executive summary comparing their company results with that of all other participating companies. Response rates ranged from $62 \%$ in the health care company to $85 \%$ in the utility and the pharmaceutical companies. In total, the sample included 335 respondents (69\% men; average age fell in the 40-44 range; $60.9 \%$ were middle-level managers; $23.9 \%$ senior managers). Respondents held a wide variety of positions (e.g., senior manager of marketing, sales people/managers, project manager, computer specialist), and work responsibilities were diverse, ranging from the supervision of new product development to the management of a regional sales territory, the marketing of products and services, and data collection and analysis.

As in the previous study, we measured thriving using our 10-item scale as described earlier $(1=$ strongly disagree, $7=$ strongly agree). We assessed burnout $(\alpha=.87)$ using 10 items from the Maslach Burnout Inventory (Maslach, Jackson, \& Leiter, 1996). These 10 items assessed both cynicism (e.g., "I have become more cynical about whether my work contributes to anything") and emotional exhaustion (e.g., "I feel that working all day is a strain for me"). As in the physical facilities sample, we controlled for demographics (gender, age, and years of experience), as well 
as job satisfaction and organization commitment. We measured job satisfaction $(\alpha=.93)$ using three items (e.g., "In general, I am satisfied with my job") from Hackman and Oldham (1980) and organizational commitment $(\alpha=.68)$ using three items (e.g., "I talk up my company as a great organization to work for") from Brockner and colleagues (2004). Participants responded to all items using a seven-point scale $(1=$ strongly disagree, $7=$ strongly agree $)$.

Executive Master of Business Administration degree sample. The third sample included managers enrolled in an EMBA program of a large Western university. Designed for working professionals, the EMBA program enrolls managers with a minimum of eight years of work experience and an average of 15 years of work experience. Those in the program generally hold positions with significant management responsibility or entrepreneurial roles. These individuals work in a wide variety of industries, including advertising, marketing, public relations, entertainment, education, community service, retail/sales, hospitality/restaurant, manufacturing, and others. At the time of the study, the EMBAs were completing their final course in the program, which focused on leadership development.

After the introduction of the study in class, we sent an email inviting their participation. We achieved a $64 \%$ response rate, resulting in a sample of 136 respondents (66\% men; average age was 33 years, with a range of 24-55). Respondents and non-respondents differed in terms of age (respondent mean $=34.1$ years and non-respondent mean $=31.7$ years) but did not differ in terms of gender or industry.

We employed the same measures of thriving at work as in the other samples. Given that all respondents were managers, we used Kouzes and Posner's (2002) Leadership Practices Inventory to capture their performance as leaders. Researchers extensively used the Leadership Practices Inventory in diverse settings ranging from fully employed MBAs (Stanko, 2008), nurses (Torangeau, 2003), bank managers (Carless, Wearing, \& Mann, 2000) to managers of engineering firms (Herold \& Fields, 2004), in multiple cultures and both the public and private sectors (Posner \& Kouzes, 1988). Across these studies, the scale has been found to be reliable and predictive of relevant leadership outcomes, including financial performance and overall leadership effectiveness. To reduce the potential for common method bias, respondents' bosses responded to 30 statements $(\alpha=.92)$ — six statements measuring each of the five key practices of exemplary leaders on 10-point Likert scales $(1=$ almost never do and $10=$ almost always do $)$ - that is, modeling the way (e.g., "setting a positive example of how work should be done"), inspiring a shared vision (e.g., "envisioning a future"), challenging the process (e.g., "seeking opportunities to take initiative and make change"), enabling others to act (e.g., "fostering collaboration"), and encouraging the heart (e.g., "recognizing the contributions of others").

Health was captured by measures of job strain and a general measure of health. Job strain $(\alpha=.84)$ was assessed with seven items (e.g., how much has your job made you feel tense) derived from Warr's (1990) scale of anxietycontentment used by Parker and Sprigg (1999) by using a seven-point scale ( $1=$ strongly disagree, 7 = strongly agree $)$. The general health questionnaire $(\alpha=.83$ ), composed of 12 items (e.g., have you been able to concentrate on whatever you are doing), assessed respondents' general health and psychological well-being over the last few weeks (Jackson, 2007), using a four-point scale (1= much less than usual, $4=$ much more than usual).

We controlled not only for basic demographics (e.g., gender and age) but also for organizational commitment and career satisfaction. Because many respondents in our sample experienced substantial changes in their careers during and after the MBA program, we controlled for career satisfaction rather than for job satisfaction in this study. We measured career satisfaction $(\alpha=.94)$ using five items (e.g., "In the past six months I have felt satisfied with the progress I've made toward meeting my goals for advancement") from Greenhaus, Parasuraman, and Wormley (1990), with individuals providing responses, using a seven-point scale $(1=$ strongly disagree, $7=$ strongly agree $)$. We assessed organizational commitment $(\alpha=.75)$ using the same items used in the previous study.

\section{Results}

Before testing our hypotheses, we confirmed the factor structure of the thriving construct. As shown in Tables 6 and 7, we found good support for the two-dimensional second-order factor structure of thriving in both samples $\left(\Delta \chi^{2}\right.$ $(1)=145.87, p<.01$, for plant sample; $\Delta \chi^{2}(1)=277.93, p<.01$, for multicompany sample), with each dimension 
Table 6. Confirmatory factor analysis results across plant facilities and multicompany samples.

Items Plant facilities

Multicompany

"At work, ..."

Learning latent factor

... I find myself learning often

... I continue to learn more and more as time goes by

... I see myself continually improving

... I am not learning (R)

... I have developed a lot as a person

Vitality latent factor

... I feel alive and vital

... I have energy and spirit

... I do not feel very energetic (R)

... I feel alert and awake

... I am looking forward to each new day

Learning-thriving second-order loading

Table 7. Confirmatory factor analysis (CFA) results for thriving across plant facilities and multicompany samples.

\begin{tabular}{lcccc}
\hline Fit statistic & $\begin{array}{c}\text { Second-order CFA } \\
\text { plant facilities }\end{array}$ & $\begin{array}{c}\text { Single-factor } \\
\text { plant facilities }\end{array}$ & $\begin{array}{c}\text { Second-order CFA } \\
\text { multicompany sample }\end{array}$ & $\begin{array}{c}\text { Single-factor } \\
\text { multicompany sample }\end{array}$ \\
\hline Degrees of freedom $(d f)$ & 34 & 35 & 34 & 35 \\
Chi-square $\left(\chi^{2}\right)$ & $\begin{array}{c}86.20 \\
(p=.001)\end{array}$ & $\begin{array}{c}202.07 \\
(p=.001)\end{array}$ & $\begin{array}{c}132.27 \\
(p=.001)\end{array}$ & $\begin{array}{c}410.37 \\
(p=.001)\end{array}$ \\
Difference in $\chi^{2}$ & $\begin{array}{c}115.87, d f=1 \\
(p=.001)\end{array}$ & & $\begin{array}{c}277.93, d f=1 \\
(p=.001)\end{array}$ & .06 \\
Root mean square residual & .03 & .05 & .09 & .08 \\
Root mean square error of & .11 & .23 & .98 & .13 \\
approximation & .98 & .94 & .96 & .90 \\
Comparative fit index & .96 & .91 & .87 \\
Relative fit index & & &
\end{tabular}

exhibiting acceptable internal consistencies and reliabilities. Again, we computed thriving as the composite of vitality and learning.

We presented means, standard deviations, and correlations in Tables 8 (physical facilities sample), 9 (multicompany sample), and 10 (EMBA sample). To test our hypotheses, we used regression analysis (in the case where we had more than one dependent variable, we used multivariate multiple regressions (using the generalized linear model procedure in SPSS (IBM Corporation, Somers, NY, USA; Dwyer, 1983)). We controlled for the effects of basic demographics (e.g., gender, age) as well as job satisfaction and organizational commitment. In the multicompany study, we also controlled for company by including company dummy codes as well as employee level. As expected, thriving was negatively related to burnout $(\beta=-.57, p<.001$; Table 11$)$ in the multicompany sample, providing support for Hypothesis 6 . In the physical facilities sample, thriving was positively related to employees' career development initiative $\left(\beta=.52, p<.001, \Delta R^{2}=.02\right.$; Table 12) and individual job performance $\left(\beta=.31, p<.01, \Delta R^{2}=.03\right.$; Table 12), both rated by their supervisors, providing support for Hypotheses 7 and 8 . In the EMBA sample, thriving was positively related to leadership effectiveness $(\beta=.43, p<.001$, $\Delta \mathrm{R}^{2}=0.08$; Table 13), as rated by their bosses, providing additional support for Hypothesis 8 . 
Table 8. Descriptive statistics and correlation matrix, plant facilities sample.

\begin{tabular}{|c|c|c|c|c|c|c|c|c|c|c|c|}
\hline \multicolumn{2}{|c|}{ Variable } & \multirow{2}{*}{$\begin{array}{r}\text { Mean } \\
.23\end{array}$} & \multirow{2}{*}{$\begin{array}{c}\text { Median } \\
0.0\end{array}$} & \multirow{2}{*}{$\frac{S D}{0.42}$} & \multirow[t]{2}{*}{1} & \multirow[t]{2}{*}{2} & \multirow[t]{2}{*}{3} & \multirow[t]{2}{*}{4} & \multirow[t]{2}{*}{5} & \multirow[t]{2}{*}{6} & \multirow[t]{2}{*}{7} \\
\hline 1 & Gender & & & & & & & & & & \\
\hline 2 & Age & 43.04 & 44.00 & 9.88 & .02 & & & & & & \\
\hline 3 & Thriving & 3.59 & 3.80 & 0.78 & -.06 & -.08 & $(.94)$ & & & & \\
\hline 4 & Job satisfaction & 3.81 & 4.00 & 0.83 & -.09 & -.08 & $.72 * *$ & $(.93)$ & & & \\
\hline 5 & Organizational commitment & 3.82 & 4.00 & 0.78 & $-.14 *$ & -.09 & $.41 * *$ & $.49 * *$ & $(.91)$ & & \\
\hline 6 & Career development initiative & 3.32 & 3.24 & 0.81 & -.08 & -.03 & $.40 * *$ & $.25 * *$ & $.20 * *$ & $(.94)$ & \\
\hline 7 & Performance & 3.72 & 3.75 & 0.85 & -.04 & .06 & $.29 * *$ & $.23 * *$ & $.24 * *$ & $.58 * *$ & $(.88)$ \\
\hline
\end{tabular}

Note: Cronbach's alpha reliabilities of each measure displayed on the diagonal of the matrix (in parentheses).

$* p<.05$ (two-tailed); ** $p<.01$ (two-tailed).

In the EMBA sample, thriving was also positively related to general health $\left(\beta=.25, p<.05, \Delta \mathrm{R}^{2}=.03\right.$; Table 14$)$ and negatively related to job strain $\left(\beta=-.44, p<.001, \Delta \mathrm{R}^{2}=.10\right)$, providing support for Hypothesis 9 . When people experience thriving at work, they report better health. Of particular interest is that these findings hold, even after controlling for the effects of more traditional attitudinal predictors of important organizational outcomes (i.e., job satisfaction and organizational commitment) and for the included demographic controls; that thriving explains an incremental $10 \%$ of the variance in burnout, $8 \%$ in career development initiative, $4 \%$ in job performance, $9 \%$ in leader effectiveness, $10 \%$ in job strain, and $3 \%$ in general health. Overall, these findings build further support for the construct validity of thriving.

\section{Study 3}

In Study 3, we focus explicitly on the contextual embeddedness of thriving at work, arguing that thriving will vary depending on the work context. Specifically, we expect that the experience of thriving is likely to change along with meaningful changes in the dynamics at work because of its social embeddedness. Rather than changing in the moment as an episodic emotion might do, we expect people to experience a change in their thriving as circumstances in their work environment change in some substantial way. For example, if one's role changes - that is, one is asked to take on a new

Table 9. Descriptive statistics and correlation matrix, multicompany sample.

\begin{tabular}{|c|c|c|c|c|c|c|c|c|c|c|c|c|}
\hline \multicolumn{2}{|c|}{ Variable } & \multirow{2}{*}{$\begin{array}{r}\text { Mean } \\
1.31\end{array}$} & \multirow{2}{*}{$\begin{array}{c}\text { Median } \\
1.0\end{array}$} & \multirow{2}{*}{$\begin{array}{l}S D \\
0.46\end{array}$} & \multirow[t]{2}{*}{1} & \multirow[t]{2}{*}{2} & \multirow[t]{2}{*}{3} & \multirow[t]{2}{*}{4} & \multirow[t]{2}{*}{5} & \multirow[t]{2}{*}{6} & \multirow[t]{2}{*}{7} & \multirow[t]{2}{*}{8} \\
\hline 1 & Gender & & & & & & & & & & & \\
\hline 2 & Age & 5.54 & 6.0 & 1.63 & -.03 & & & & & & & \\
\hline 3 & Level & 2.27 & 2.0 & 0.69 & -.07 & .03 & & & & & & \\
\hline 4 & Education & 4.28 & 4.0 & 1.51 & -.01 & -.04 & $.12 *$ & & & & & \\
\hline 5 & $\begin{array}{l}\text { Organizational } \\
\text { commitment }\end{array}$ & 5.73 & 6.0 & 0.92 & $.13^{*}$ & .05 & $.19 *$ & .03 & $(.68)$ & & & \\
\hline 6 & Job satisfaction & 5.53 & 6.0 & 1.22 & .02 & .08 & $.11 *$ & .01 & $.78 * *$ & $(.93)$ & & \\
\hline 7 & Thriving & 5.29 & 5.5 & 0.87 & .05 & .07 & $.13 *$ & .02 & $.76^{* *}$ & $.81^{*}$ & $(.90)$ & \\
\hline 8 & Burnout & 2.90 & 2.8 & 1.03 & -.01 & -.04 & $-.12 *$ & -.04 & $-.57 * *$ & $-.68 * *$ & $-.74 * *$ & (.87) \\
\hline
\end{tabular}

Notes: $N=335$. Cronbach's alpha reliabilities are on the diagonal. Reliabilities of each measure displayed on the diagonal of the matrix (in parentheses).

$* p<.01 ; * * p<.001$. 
THRIVING AT WORK

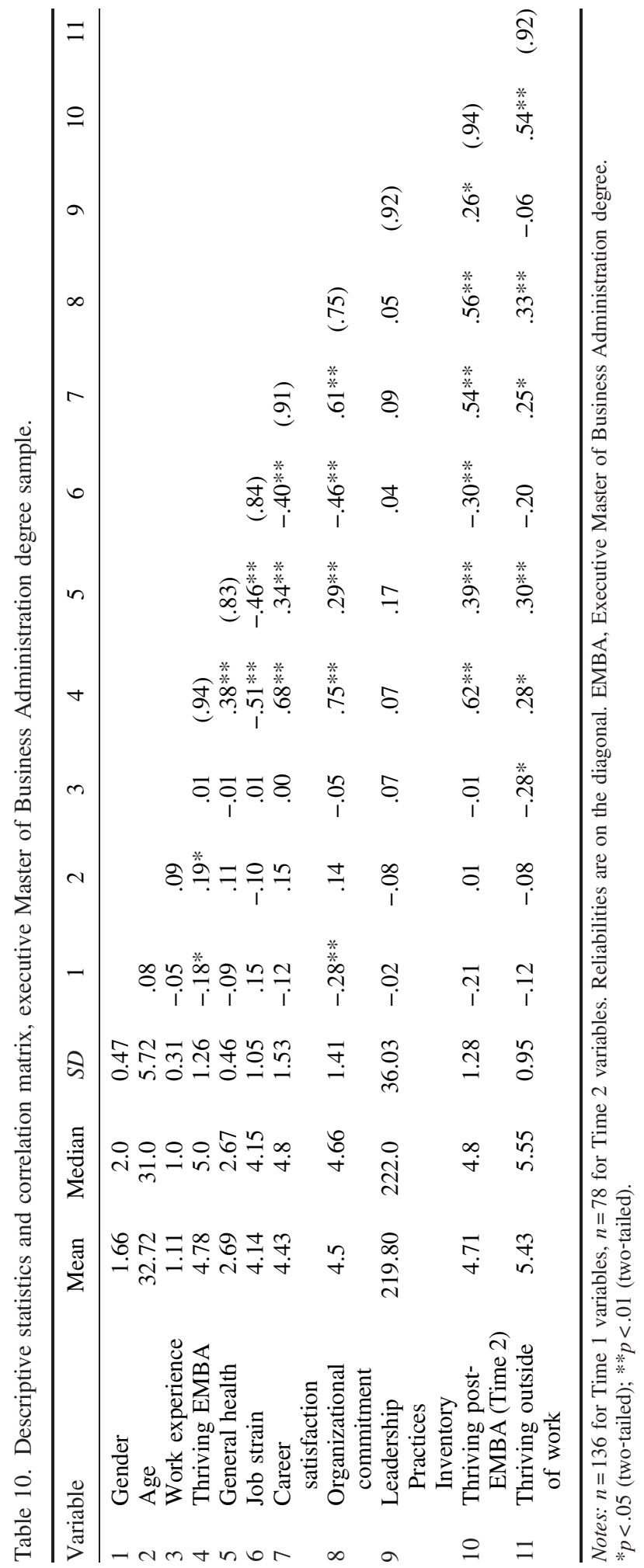


Table 11. Regression estimates of thriving on burnout (multicompany sample).

\begin{tabular}{lrr}
\hline Variables & & Burnout \\
\hline Company 1 & -.01 & -.01 \\
Company 2 & .01 & .04 \\
Company 3 & -.10 & -.06 \\
Company 4 & $-.10 *$ & -.07 \\
Company 5 & $-.15 *$ & $-.11^{*}$ \\
Gender & -.02 & -.01 \\
Education & -.05 & -.05 \\
Age & -.01 & -.02 \\
Level & -.04 & -.04 \\
Organizational commitment & -.13 & .08 \\
Job satisfaction & $-.57 * * *$ & $-.28 * * *$ \\
Thriving & & $-.57 * * *$ \\
$R^{2}$ & & .59 \\
Adj $R^{2}$ & .49 & .58 \\
$F$ & .48 & $35.94 * * *$ \\
$R^{2}$ & $26.74 * * *$ & $.10^{* * *}$ \\
\hline
\end{tabular}

$n=312$. Values in cells are standardized betas.

$* p<.05 ; * * * p<.001$.

responsibility — or if one changes jobs, his or her experience of thriving is also likely to change. To this end, Niessen, Sonnentag, and Sach (2010) found in their recent research that reports of thriving vary substantially across days.

In an attempt to assess the temporality of thriving, we followed up with our EMBA sample described earlier one month after completing their program. As such, we have two separate assessments of thriving at two different points in time: (i) during the EMBA program and (ii) one month later, after completion of the EMBA program. During the month that separated these two measurements, some participants experienced changes in their roles, responsibilities, discretion, and task structure at work. At the very least, participants no longer had to juggle a fulltime job alongside a rigorous MBA curriculum, which included substantial time outside of work. Because we believe thriving to be contextually embedded, we expect the assessment of thriving to vary based on the specific circumstances at work. Therefore, we expect low to moderate correlations across the two points in time, given changes in the work context following the end of the EMBA program. In short, we expect thriving to vary across time points as a person's work environment changes.

Table 12. Multivariate multiple regression estimates of thriving on career initiative and job performance (plant facilities).

\begin{tabular}{|c|c|c|c|c|}
\hline \multirow{2}{*}{$\begin{array}{l}\text { Variables } \\
\text { Gender }\end{array}$} & \multicolumn{2}{|c|}{ Career development initiative } & \multicolumn{2}{|c|}{ Job performance } \\
\hline & .00 & .00 & .01 & .01 \\
\hline Age & -.06 & -.07 & -.11 & -.11 \\
\hline Job satisfaction & -.01 & -.19 & .11 & .00 \\
\hline Organizational commitment & $.31 *$ & .06 & .17 & .02 \\
\hline Thriving & & $.52 * * *$ & & $.31 * *$ \\
\hline$R^{2}$ & .08 & .18 & .07 & .10 \\
\hline $\operatorname{Adj} R^{2}$ & .06 & .16 & .05 & .07 \\
\hline$F$ & $4.05^{* *}$ & $7.94 * * *$ & $3.33 * *$ & $3.99 * *$ \\
\hline$\Delta R^{2}$ & & $.10 * * *$ & & $.03 * *$ \\
\hline
\end{tabular}

Note: Values in cells are standardized betas. Career development initiative and job performance were tested using multivariate multiple regression, $n=188$.

$* p<.05 ; * * p<.01 ; * * * p<.001$. 
Table 13. Regression estimates of thriving on leader effectiveness (Executive Master of Business Administration degree sample).

\begin{tabular}{lcc}
\hline Variables & & Leader effectiveness \\
\hline Employment & .06 & .04 \\
Gender & -.05 & .03 \\
Age & -.13 & -.13 \\
Career satisfaction & .08 & -.22 \\
Thriving & & $.43^{* * *}$ \\
$R^{2}$ & .04 & .12 \\
Adj $R^{2}$ & .0 & .04 \\
$F$ & .05 & 1.41 \\
$\Delta R^{2}$ & & $.08^{*}$ \\
\hline
\end{tabular}

$n=55$. Values in cells are standardized betas.

$* p<.05 ; * * p<.01 ; * * * p<.001$.

Hypothesis 10a: Thriving will vary across time points as a person's work environment changes.

We further suggest that an individual's level of thriving may be different across two contexts: (i) thriving at work and (ii) thriving in one's personal life, with family, friends, hobbies, and in their community. Although we expect there to be some spillover from one to the other, we believe the experience of thriving to be distinct in each aspect of an individual's life. For instance, although one may feel as though he or she is languishing at work, one may simultaneously be thriving in his or her non-work life, whether through the enjoyment of stimulating relationships with family and friends, pouring time into rewarding volunteer efforts within his or her community, committing more time and energy in spiritual exercises and causes, and/or engaging in more physical training workouts for a triathlon. However, it is possible that if an individual is thriving at work, they might neglect aspects of their non-work life (Halbesleben, Harvey, \& Bolino, 2009), leading to a sense that their non-work life is languishing. That is, people who are thriving at work may be pulled into investing more of themselves into that work role but to the detriment of thriving outside of work. We do not claim that thriving at work and home are completely orthogonal—in fact, there are strategies for combining aspects of one's life so that people feel a sense of thriving at work and in non-work life (Friedman, 2008)—but for many, thriving in both contexts may be challenging. Thus, we expect that

Hypothesis 10b: Thriving will vary across work and non-work contextual referents.

Table 14. Multivariate multiple regression estimates of thriving on general health and job strain (Executive Master of Business Administration degree sample).

\begin{tabular}{lcccc}
\hline Variables & \multicolumn{2}{c}{ General health } & \multicolumn{2}{c}{ Job strain } \\
\hline Employment & -.02 & -.02 & .02 & .02 \\
Gender & -.05 & -.03 & .11 & .06 \\
Age & .07 & .04 & -.05 & -.01 \\
Career satisfaction & $.34^{* *}$ & .17 & $-.37^{* * *}$ & -.09 \\
Thriving & & $.25^{*}$ & & $-.44^{* * *}$ \\
$R^{2}$ & .13 & .16 & .17 & .27 \\
Adj $R^{2}$ & .10 & .13 & .14 & .24 \\
$F$ & $4.93^{* *}$ & $5.08^{* * *}$ & $6.07^{* * *}$ & $9.59^{* * *}$ \\
$\Delta R^{2}$ & & $.03^{*}$ & & $.10^{* * *}$ \\
\hline
\end{tabular}

$n=136$. Values in cells are standardized betas.

$* p<.05 ; * * p<.01 ; * * * p<.001$. 


\section{Method}

\section{Sample and measures}

For this study, we used the same EMBA sample presented in the second study. We measured thriving at work at two points in time. At the one-month post-EMBA juncture, we emailed respondents asking them to participate in a brief follow-up survey in exchange for a $\$ 10$ gift certificate or donation to a charity. Of those who responded to the first survey, 78 responded one month later, for a response rate of $57 \%$. At the post-EMBA assessment, we again measured thriving and also included a measure of thriving in life outside of work $(\alpha=.92)$, which used the same items as the thriving at work measure used in the previous studies but referenced participants' life outside of work to include personal relationships (e.g., with family, friends), any hobbies, and volunteer efforts, for example.

\section{Results}

Before testing our hypotheses, we examined the factor structure of the thriving construct and, once again, found good support for the two-dimensional second-order factor structure of thriving versus the single-factor structure $\left(\Delta \chi^{2}(1)=67.36, p<.01\right)$. As in the previous studies, we computed thriving as the composite of vitality and learning. We presented means, standard deviations, and correlations in Table 10.

To investigate the extent to which thriving changes over time, we examined the variance shared by thriving at work during respondents' participation in their EMBA program and one month after completing this program. Consistent with our expectations, the relationships between thriving at work during the EMBA program and postEMBA was significant $\left(R^{2}=.37, p<.001\right)$; however, the correlation suggests that thriving assessments do vary over time. In short, the variance explained indicates that thriving varies over time as aspects of an individual's work life changes, providing support for Hypothesis 10a.

Not only does thriving vary over time, but we also found thriving to vary across contexts. Thriving outside of work was positively related to thriving at work during the same time $\left(R^{2}=.28, p<.001\right)$, although the shared variance suggests that individuals can be thriving at a different level in one aspect of life (e.g., work) than in another aspect (e.g., non-work). Viewed another way, post hoc analyses indicate that among the 17 individuals who are one standard deviation above the mean on thriving at work, only four (less than 25\%) are also one standard deviation above the mean on thriving outside of work. Similarly, among the 14 individuals who are one standard deviation above the mean on thriving outside of work, only five are also one standard deviation above the mean on thriving at work. These findings support our expectations that thriving varies across work and non-work contexts, consistent with Hypothesis $10 \mathrm{~b}$.

\section{General Discussion}

A key contribution of our research is the theoretical refinement of the thriving construct and empirical validation of its measure. Across multiples samples, we provide support for the two-dimensional conceptualization of thriving, with results suggesting that thriving contributes to human sustainability (Pfeffer, 2010) through psychological (reduced burnout) and physical (perceptions of health) well-being. Our work also extends prior research by demonstrating the link between thriving and adaptive behaviors such as career development initiative and job performance, addressing calls in the POB and POS literatures (e.g., Cameron et al., 2003; Luthans \& Youssef, 2007) for research on constructs that have direct impact on performance and well-being. Specifically, this research contributes to the POB literature by developing and by validating a cognitive and affective mechanism that impacts performance as well as a host of other outcomes. Thriving is a construct that, in line with POB, can be used to effectively manage performance improvement in the workplace. For the POS literature, thriving represents an 
especially positive process for an organization's members. It drives a number of positive behaviors, as evidenced in this and other (e.g., Porath, Spreitzer \& Gibson, 2008) research.

Our research sets out to answer several important questions pertaining to the construct validity of thriving, including its dimensionality: (i) Do we need a thriving construct? (ii) Do we need a multidimensional construct of thriving? (iii) Should we focus on thriving at work? (iv) To what extent is thriving dynamic?

First, do we need a thriving construct? We show that thriving at work contributes to organizational studies beyond the more traditional constructs used to explain performance, such as job satisfaction and organizational commitment. The construct of thriving at work harnesses ideas of positive growth and development, similar to other insights focusing on individual growth at work, but is better supported empirically than these other theories, such as self-actualization (Maslow, 1943) and growth-need-strength (Hackman \& Oldham, 1980), for example. Throughout the construct validation process, we were mindful of prior criticisms of the POB and POS literatures (Hackman, 2009) including the historical character of research and writing, the lack of a rigorous construct validity process, and methods free of common method variance that have discriminant and convergent validity. Specifically, we rooted thriving at work in its earliest psychological foundations. We provided theoretical refinement of the construct and demonstrated its validity by examining the relationship between thriving and other constructs in its nomological network. In so doing, we not only collected data from respondents and their managers in an attempt to mitigate common method bias but also answered previous calls by examining thriving across different settings and with a variety of samples (Luthans \& Youssef, 2007), ranging from young adults to much older, well-seasoned managers; from those who spend their time in academic settings (i.e. students, MBAs) to those who work in an extraordinary range of companies and industries (both in terms of type and the context); and from those who hold blue-collar jobs to those who serve as top executives in white-collar, professional settings.

Second, do we need a multidimensional construct of thriving at work rather than simply examining its two dimensions of vitality and learning separately? At a most basic level, there are many multidimensional constructs in both organizational behavior and psychology more broadly that capture something beyond the individual dimensions themselves - for example, transformational leadership (Bass \& Avolio, 1994), organizational citizenship (Organ, 1988), psychological empowerment (Spreitzer, 1995), burnout (Maslach, 2003), core self-evaluations (Judge et al., 2003), psychological capital (Luthans, Avolio, et al., 2007), inspiration (Thrasher \& Elliot, 2003). Like these other multidimensional constructs, thriving is the experience of an individual's growth and momentum, which is not fully captured by either a sense of vitality or learning. Rather, these two dimensions together, representing thriving at work, capture the affective and cognitive components of individual growth and development in a work context.

Third, should we focus on thriving at work rather than thriving in life more generally? We offer several reasons for why thriving at work, specifically, is important. First, work is a context where people are spending increasing amounts of their waking hours (Schor, 1993). Although positive psychology has focused on positive states regardless of context, the literatures on positive organizational behavior and positive organizational scholarship look explicitly at a work or organizational context. Scholars have explicitly called for development and validation of measures of positive constructs that are "specific and valid for the workplace" (Luthans \& Youssef, 2007, p. 340). Second, the support we find regarding the relationship between thriving both within and outside of work suggests that thriving in a work context is distinct from thriving outside of work. As organizational scholars, we want to understand the psychological state that is most influenced by the context of work rather than private life. Third, our findings further indicate the specific ways in which thriving at work is valuable not only for the individuals who experience thriving but also for their organizations as well-that is, thriving relates to lower levels of burnout, higher job performance, and more positive health.

Fourth, to what extent is thriving dynamic and embedded in the work context? The third study allowed us to better understand the contextual embeddedness of thriving. The correlations between thriving during the EMBA program and post-EMBA indicate that thriving varies over time, as would be expected because the job context changed in substantial ways during and after the program. If thriving scores were relatively constant across the two points in time, then we might infer that it is not influenced by the environment. Moreover, we found that thriving varies across work and nonwork contexts as well. Although there was some spillover between thriving at work and thriving outside of work, 
respondents see their thriving across the two contexts as relatively distinct. Simply because a person is thriving at work does not suggest a comparable level of thriving outside of work. The referent for the assessment of thriving matters.

\section{Limitations and Directions for Future Research}

First, although we do have "other" reports of the outcome variables, we do not have a longitudinal or experimental design to tease out the causality of the relationships, particularly with regard to thriving over the course of time. Future research would benefit from methodological designs that ascertain directionality of the relationships. In particular, research investigating the long-term health benefits of thriving would be useful. Future research should also study thriving at work over shorter time in an effort to better understand the microdynamics of thriving, particularly its ebbs and flows using experience sampling or diaries (for an example, Niessen et al., 2010). Research investigating thriving over the course of intense projects or transition periods would provide a better understanding of what causes variability in thriving over time and across contexts.

Second, we do not address the dispositional bases of thriving. Thus, future research may seek to develop a trait-based measure of thriving, as in the case for other constructs such as learning orientation, which has both trait-like and state-like operationalizations. Interestingly, this work would help to show whether some individuals are more inclined than others to thrive across a broad range of situations. It will also be useful to examine thriving in relation to other positive constructs such as psychological capital (Luthans, Youssef, et al., 2007). Future research can provide a "known groups analysis" of people who are already known to be thriving a priori to see whether the expected patterns of relationships are even more profound. This analysis could provide insight into how people self-regulate their thriving successfully for exceptional outcomes. Our research design did not allow for a test of the self-regulatory nature of thriving (i.e., the repeated cycles of within-person thriving); however, it is an important area for future research.

Even if some individuals are more predisposed to thriving than others-or better able to use thriving as a selfregulatory gauge-it would be useful to develop a stronger understanding of the role of the context on thriving at work. For example, what aspects of work design enhance thriving? What roles do leaders play in enabling thriving? As a starting point, Spreitzer and colleagues (2005) suggested some contextual factors that may enable thriving, such as discretion, broad information sharing, and a climate of trust/respect.

Finally, there is much more to be learned about how thriving at work and outside of work interrelate. Perhaps thriving at work fuels people with positive feelings, energy, and self-efficacy that, consequently, sparks thriving outside of work, carrying over to non-work activities in meaningful (and perhaps unconscious) ways. On the other hand, maybe thriving at work pulls people into more work, tipping the balance heavily in favor of energy and focus in work activities. Consistent with recent research (Halbesleben et al., 2009), thriving at work may leave very little space for activities outside of work, contributing to detrimental effects on families, for example. Even if thriving at work is beneficial in the short term, what might be the long(er) term effects of thriving at work on burnout and other health outcomes, family and friend relationships, and overall well-being? Longitudinally, we might trace careers and learn how people can thrive within and outside of work to achieve the best personal and professional outcomes. Are there ways to combine work and non-work thriving in each context, as suggested by the work of Friedman (2008)? Relatedly, does thriving change over the life course and life contexts? Does this vary by culture? These seem like fruitful areas for future research because there are meaningful practical implications for both individuals and organizations.

\section{Conclusion}

From a practical perspective, our results offer some implications for individual thriving at work. Although people need to monitor external indicators of progress, attention to internal cues, particularly thriving, may also provide a 
helpful basis for self-regulation. When people pay attention to how they feel, they are better able to pursue opportunities for learning and recovering energy (Sonnentag \& Fritz, 2007). Thriving employees are less susceptible to burnout and more likely to take an active role in developing a successful career path, which is particularly important given today's protean careers (Hall, 1998). Thriving is also associated with reduced job strain and increased general health and well-being. An emphasis on promoting thriving at work could also be a relatively cost-efficient way to reduce absenteeism and stress, which is highly correlated with health care costs (Leiter \& Maslach, 2005).

To take advantage of the benefits of thriving, managers need to gauge employee thriving and find ways to promote it. Recent research suggests that organizations can facilitate thriving through decision-making discretion, broad information sharing, feedback and a climate of civility (Porath et al., 2008). By focusing on these contextual features, managers will increase thriving, performance, and organizational citizenship behaviors and reduce health care costs. Monitoring employee thriving and increasing opportunities for employee learning and development will serve the organization well. In short, our results indicate the potential for thriving to be a potent force driving human sustainability at work.

\section{Acknowledgements}

We thank Adam Cobb, Chak Fu Lam, Adam Grant, Scott Sonenshein, and J. Craig Wallace for their comments on earlier versions of this manuscript. Rick Bagozzi and Jeff Edwards offered helpful insights on our analyses. We thank Adam Grant and Kathleen Sutcliffe for their help with data collection on the two pilot studies. We thank Susan Ashford, Kim Cameron and Jane Dutton for their collaboration on the data collection for the young professionals sample. We thank Senn-Delaney for their assistance with data collection - and the respondents for their participation in the research. We also thank the Ross School of Business and the University of California at Irvine for their financial support of this research.

\section{Author biographies}

Christine Porath is an Assistant Professor at the McDonough School of Business at Georgetown University. Her research focuses not only on the effects of incivility, but also how organizations can create a more positive environment where people can thrive; and how individuals and organizations benefit in terms of individual wellbeing and performance.

Gretchen Spreitzer is Professor of Management and Organizations at the University of Michigan. Her research focuses on employee empowerment and leadership development, particularly during times of change. She is part of the Center for Positive Organizational Scholarship where her recent research is on enabling employee thriving at work.

Cristina Gibson is Winthrop Professor of Management and Organization at the University of Western Australia School of Business. Her area of expertise is the nexus of organizational behavior, international management, and cross-cultural psychology, with a focus on collective cognition, interaction and effectiveness in teams and the impact of culture on work behavior.

Flannery G. Garnett is an Assistant Professor of Management at the Eccles School of Business at the University of Utah. She received her Ph.D. in management and organizations from the University of Michigan. Her research focuses on the sources and consequences of inequality in organizations at the micro and macro levels. 


\section{References}

Alderfer, C. (1972). Existence, relatedness, and growth; human needs in organizational settings. New York: Free Press.

Alfredsson, L., Spetz, L., \& Theorell, T. (1985). Type of occupation and near-future hospitalization for myocardial infarction and some other diagnoses. International Journal of Epidemiology, 14, 378-388.

Ashford, S. J., \& Black, J. S. (1996). Proactivity during organizational entry: The role of desire for control. The Journal of Applied Psychology, 81, 199-214.

Bandura, A. (2001). Social cognitive theory: An agentic perspective. Annual Review of Psychology, 52, 1-16.

Bass, B. M., \& Avolio, B. J. (1994). Improving organizational effectiveness through transformational leadership. Thousand Oaks, CA: Sage Publications.

Bateman, T., \& Crant, M. (1993). The proactive component of organizational behavior. Journal of Organizational Behavior, 14, 103-118.

Benson, P., \& Scales, P. (2009). The definition and preliminary measurement of thriving in adolescence. The Journal of Positive Psychology, 4, 85-104.

Brockner, J., \& Higgins, E. T. (2001). Regulatory focus theory: Its implications for the study of emotions in the workplace. Organizational Behavior and Human Decision Processes, 86, 35-66.

Brockner, J., Spreitzer, G., Mishra, A., Hochwater, W., Pepper, L., \& Weinberg, J. (2004). Perceived control as an antidote to the negative effects of layoffs on survivors' organizational commitment and job performance. Administrative Science Quarterly, 49, 76-100.

Brown, J. D., \& Dutton, K. A. (1995). The thrill of victory, the complexity of defeat-Self-esteem and peoples emotionalreactions to success and failure. Journal of Personality and Social Psychology, 68, 712-722.

Bruch, H., \& Ghoshal, S. (2003). Unleashing organizational energy. Sloan Management Review, 45-51.

Button, S., Mathieu, J., \& Zajac, D. (1996). Goal orientation in organizational behavior research: A conceptual and empirical foundation. Organizational Behavior and Human Decision Processes, 67, 26-48.

Calhoun, L., \& Tedeschi, R. (1998). Beyond recovery from trauma: Implications for clinical practice and research. Journal of Social Issues, 54, 357-371.

Cameron, K. S., J. E. Dutton, \& Quinn, R. E. (2003). Positive organizational scholarship. San Francisco, CA: Barrett-Koehler.

Campbell, C. H., Ford, P., Rumsey, M. G., \& Pulakos, E. D. (1990). Development of multiple job performance measures in a representative sample of jobs. Personnel Psychology, 43, 277-300.

Campbell, J. D., Trapnell, P. D., Heine, S. J., Katz, I. M., Lavallee, L. F., \& Lehman, D. R. (1996). Self-concept clarity: Measurement, personality correlates and cultural boundaries. Journal of Personality and Social Psychology, 70, 141-156.

Carless, S. A., Wearing, A. J., \& Mann, L. (2000). A short measure of transformational leadership. Journal of Business and Psychology, 14, 389-405.

Carver, C. S. (1998). Resilience and thriving: Issues, models, and linkages. Journal of Social Issues, 54, $245-266$.

Chen, F., Curran, P., Bollen, K., Kirby, J., \& Paxton, P. (2008). An empirical evaluation of the use of fixed cutoff points in RMSEA test statistics in structural equation models. Sociological Methods \& Research, 1, 462-494.

Crant, J. M. (1995). The proactive personality scale and objective job performance among real estate agents. The Journal of Applied Psychology, 80, 532-537.

Cronbach, L. J., \& Meehl, P. E. (1955). Construct validity in psychological tests. Psychological Bulletin, 52, $281-302$.

Deci, E. L., \& Ryan, R. M. (2000). The what and why of goal pursuits: Human needs and the self-determination of behavior. Psychological Inquiry, 11, 227-268.

DeVellis, R. F. (2003). Scale development: Theory and applications (2nd edn). Thousand Oaks, CA: Sage Publications.

Dweck, C. S., \& Leggett, E. L. (1988). A social-cognitive approach to motivation and personality. Psychological Review, 95, $256-273$.

Dwyer, J. H. 1983. Statistical models for the social and behavioral sciences. New York: Oxford University Press.

Edmondson, A. (1999). Psychological safety and learning behavior in work teams. Administrative Science Quarterly, 44, 350-383.

Elliot, A. J., \& Harackiewicz, J. M. (1996). Approach and avoidance achievement goals and intrinsic motivation: A mediational analysis. Journal of Personality and Social Psychology, 461-475.

Ettner, S. L., \& Grzywacz, J. (2001). Workers' perceptions of how jobs affect health: A social ecological perspective. Journal of Occupational Health Psychology, 6, 101-113.

Farr, J. L., Hofmann, D. A., \& Ringenbach, K. L. (1993). Goal orientation and action control theory: Implications for industrial and organizational psychology. International Review of Industrial and Organizational Psychology, 8, $193-232$.

Fredrickson, B. (2001). The role of positive emotions in positive psychology: The broaden and build theory of positive emotions. The American Psychologist, 56, 218-226.

Fredrickson, B. L., Tugade, M. M., Waugh, C. E., \& Larkin, G. R. (2003). What good are positive emotions in crises? A prospective study of resilience and emotions following the terrorist attacks on the United States on September 11th, 2001. Journal of Personality and Social Psychology, 84, 365-376. 
Friedman, S. D. (2008). Total leadership: Be a better leader, have a richer life. Boston, MA: Harvard Business Press.

Gibson, C. B., \& Vermeulen, F. (2003). A healthy divide: Subgroups as a stimulus for team learning. Administrative Science Quarterly, 48, 202-239.

Grant, A. M., \& Ashford, S. J. (2007). The dynamics of proactivity at work. Research in Organizational Behavior, $28,3-34$.

Greenhaus, J. H., Parasuraman, S., \& Wormley, W. M. (1990). Effects of race on job and organizational experiences, job performance evaluations, and career outcomes. Academy of Management Journal, 33, 64-86.

Griffin, M. A., Neal, A., \& Parker, S. (2007). A new model of work role performance: Positive behavior in uncertain and interdependent contexts. Academy of Management Journal, 50, 327-347.

Hackman, J. R. (2009). The perils of positivity. Journal of Organizational Behavior, 30: 309-319.

Hackman, J. R., \& Oldham, G. (1980). Work redesign. Reading, MA: Addison-Wesley.

Halbesleben, J. R. B., Harvey, J., \& Bolino, M. C. (2009). Too engaged? A conservation of resources view of the relationship between work engagement and work interference with family. Journal of Applied Psychology, 94: 1452-1465.

Hall, D. T. (1998) Protean careers of the 21st century. Academy of Management Executive, 10, 4-15.

Hall, J., Roman, M. W., Thomas, S. P., Brown Travi, C., Powell, J., Tennison, C., Moyers, K., Shoffner, D. H., Broyles, T., Martin, T., \& McArthur, P. M. (2009). Thriving as becoming resolute in narrative of women surviving childhood maltreatment. American Journal of Orthopsychiatry, 79, 375-386.

Herold, D. M., \& Fields, D. L. (2004). Making sense of subordinate feedback for leadership development—Confounding effects of job role and organizational rewards. Group \& Organization Management, 29, 686-703.

Hobfoll, S. E. (2002). Social and psychological resources and adaptation. Review of General Psychology, 6, $307-324$.

Hoffman, B. J., Blair, C. A., Meriac, J. P., \& Woehr, D. J. (2007). Expanding the criterion domain? A quantitative review of the OCB literature. Journal of Applied Psychology, 92, 555-566.

Ickovics, J., \& Park, C. (1998). Paradigm shift: Why a focus on health is important. Journal of Social Issues, 54(2), 237-244. Jackson, C. (2007). The general health questionnaire. Occupational Medicine, 57, 79.

Jöreskog, K. G., \& Sörbom, D. (1993). LISREL 8: Structural equation modeling with the SIMPLIS command language. Hillsdale, NJ: Scientific Software.

Joseph, S., \& Linley, A. 2008. Trauma, recovery and growth: Positive psychological perspectives on posttraumatic stress. Hoboken, NJ: John Wiley and Sons.

Judge, T. A., Erez, A., Bono, J. E., \& Thoresen, C. (2002). Discriminant and incremental validity of four personality traits: Are measures of self-esteem, neuroticism, locus of control, and generalized self-efficacy indicators of a common core construct? Journal of Personality and Social Psychology, 83, 693-710.

Judge, T. A., Erez, A., Bono, J. E., \& Thoresen, C. J. (2003). The core self-evaluations scale: Development of a measure. Personnel Psychology, 56, 303-331.

Kanfer, R. (1990). Motivation and individual differences in learning: An integration of developmental, differential and cognitive perspectives. Learning and Individual Differences, 2, 221-239.

Keyes, C. L. M. (2002). The mental health continuum: From languishing to flourishing in life. Journal of Health and Social Behavior, 43, 207-222.

Kouzes, J. M., \& Posner, B. Z. (2002). The leadership challenge. San Francisco: Jossey-Bass.

Lee, R., \& Ashforth, B. (1990). On the meaning of Maslach's three dimensions of burnout. Journal of Applied Psychology, 75, 743-747.

Leiter, M. P., \& Maslach, C. (2005). Banishing burnout: Six strategies for improving your relationship with work. San Francisco: Jossey-Bass.

Luthans, F. (2002). The need for and meaning of positive organizational behavior. Journal of Organizational Behavior, 23, 695-706.

Luthans, F., \& Youssef, C. M. (2007). Emerging positive organizational behavior. Journal of Management, 33, $321-349$.

Luthans, F., Avolio, B., Avey, J., \& Norman, S. (2007). Positive psychological capital: Measurement and relationship with performance and satisfaction. Personnel Psychology, 60: 541-572.

Luthans, F., Youssef, C. M., \& Avolio, B. J. (2007). Psychological capital: Developing the human competitive edge. Oxford, UK: Oxford University Press.

Marks, S. R. (1977). Multiple roles and role strain: Some notes on human energy, time, and commitment. American Sociological Review, 42, 921-936.

Martocchio, J. J. (1994). Effects of conceptions of ability, and academic achievement. Journal of Applied Psychology, 79, $819-825$.

Maslach, C. (2003). Job burnout: New directions in research and intervention. Current Directions in Psychological Science, 12, 189-192.

Maslach, C., \& Leiter, M. P. (1997). The truth about burnout: How organizations cause personal stress and what to do about it. San Francisco: Jossey-Bass.

Maslach, C., Jackson, S. E., \& Leiter, M. P. (1996). The Maslach burnout inventory (3rd edn). Palo Alto, CA: Consulting Psychologists Press. 
Maslow, A. (1943). A theory of human motivation. Psychological Review, 40, 370-396.

Miller, J. B., \& Stiver, I. P. (1997). The healing connection: How women form relationships in therapy and in life. Boston: Beacon Press.

Mowday, R. T., Steers, R. M., \& Porter, L. W. (1979). The measurement of organizational commitment. Journal of Vocational Behavior, 14, 224-247.

Niessen, C., Sonnentag, S., \& Sach, F. (2010). Thriving at work: A diary study. Working paper, University of Konstanz.

Nix, G., Ryan, R. M., Manly, J. B., \& Deci, E. L. (1999). Revitalization through self-regulation: The effects of autonomous and controlled motivation on happiness and vitality. Journal of Experimental Social Psychology, 25, $266-284$.

Organ, D. W. (1988). Organizational citizenship behaviors. Lexington, MA: Lexington Books.

Parker, S. K., \& Sprigg, C. A. (1999). Minimizing strain and maximizing learning: The role of job demands, job control, and proactive personality. Journal of Applied Psychology, 84, 925-939.

Parker, S. K., Williams, H. M., \& Turner, N. (2006). Modeling the antecedents of proactive behavior at work. Journal of Applied Psychology, 91, 636-652.

Pfeffer, J. (2010). Building sustainable organizations: The human factor. Academy of Management Perspectives, $24,34-45$.

Porath, C. L., \& Bateman, T. (2006). Self-regulation: From goal orientation to job performance. Journal of Applied Psychology, 91, 185-192.

Porath, C. L., Spreitzer, G., \& Gibson, C. (2008). Antecedents and consequences of thriving across six organizations. A paper presented at the 2008 Academy of Management Meeting in Anaheim, CA.

Posner, B. Z., \& Kouzes, J. M. (1988). Development and validity of the Leadership Practices Inventory. Educational and Psychological Measurement, 48, 483-496.

Reagans, R, Argote, L., \& Brooks, D. (2005). Individual experience and experience working together: Predicting learning rates from knowing what to do and knowing who knows what. Management Science, 51, 869-881.

Rogers, C. (1961). On becoming a person: A therapist's view of psychotherapy. London: Constable

Ryan, R. M., \& Deci, E. L. (2000). Self-determination theory and the facilitation of intrinsic motivation, social development, and well-being. The American Psychologist, 55, 68-78.

Ryan, R. M., \& Frederick, C. (1997). On energy, personality, and health: Subjective vitality as a dynamic reflection of wellbeing. Journal of Personality, 65, 529-565.

Ryff, C. D. (1989). Happiness is everything, or is it-Explorations on the meaning of psychological well-being. Journal of Personality and Social Psychology, 5, 1069-1081.

Saakvitne, K. W., Tennen, H., Affleck, G. (1998). Exploring thriving in the context of clinical trauma theory: Constructivist selfdevelopmental theory. Journal of Social Issues, 54 (2), 279-299.

Schor, J. (1993). The overworked American: The unexpected decline of leisure. New York: Basic Books.

Seibert, S. E., Crant, J. M., \& Kraimer, M. L. (1999). Proactive personality and career success. Journal of Applied Psychology, 84, 416-427.

Seligman, M. E. P., \& Csikszentmihalyi, M. (2000). Positive psychology: An introduction. American Psychologist, 55, 5-14.

Seo, M. G., Barrett, L. F., \& Bartunek, J. M. (2004). The role of affective experience in work motivation. Academy of Management Review, 29, 423-439.

Sonnentag, S., \& Fritz, C. (2007). The recovery experience questionnaire: Development and validation of a measure assessing recuperation and unwinding at work. Journal of Occupational Health Psychology, 12, 204-221.

Spector, P. E. (1985). Measurement of human service staff satisfaction: Development of the job satisfaction survey. American Journal of Community Psychology, 13, 693-713.

Spreitzer, G. M. (1995). Psychological empowerment in the workplace: Dimensions, measurement, and validation. Academy of Management Journal, 38, 1442-1465.

Spreitzer, G. M., Sutcliffe, K., Dutton, J., Sonenshein, S., \& Grant, A. M. (2005). A socially embedded model of thriving at work. Organization Science, 16, 537-549.

Stanko, T. (2008). From scout leaders to business leaders: How participation in multiple roles shapes behavior at work. Dissertation, University of California, Irvine.

Thomas, S. P., \& Hall, J. (2008). Life trajectories of female child abuse survivors thriving in adulthood. Qualitative Health Research, 18, 149-166.

Thrasher, T. M., Elliot, A. J. (2003). Inspiration as a psychological construct. Journal of Personality and Social Psychology, 84 (4): 871-889.

Torangeau, A. E. (2003). Building nurse leader capacity. Journal of Nursing Administration, 33, $624-626$.

Tsui, A. S., \& Ashford, S. J. (1994). Adaptive self-regulation: A process view of managerial effectiveness. Journal of Management, 20, 93-121.

Tugade, M. M., Fredrickson, B. L., \& Feldman Barrett, L. (2004). Psychological resilience and positive emotional granularity: Examining the benefits of positive emotions on coping and health. Journal of Personality, 72, 1161-1190. 
VandeWalle, D. M. (1997). Development and validation of a work domain goal orientation instrument. Educational and Psychological Measurement, 8, 995-1015.

VandeWalle, D., Cron, W. L., \& Slocum, J. W., Jr. (2001). The role of goal orientation following performance feedback. Journal of Applied Psychology, 86, 629-640.

Warr, P. B. (1990). The measurement of well-being and other aspects of mental health. Journal of Occupational Psychology, 63, 193-210.

Watson, D., Clark, L. A., \& Tellegen, D. (1988). Development and validation of brief measures of positive and negative affect: The PANAS scales. Journal of Personality and Social Psychology, 54, 1063-1070.

Welbourne, T. M., Johnson, D. E., \& Erez, A. (1998). The role-based performance scale: Validity analysis of a theory-based measure. Academy of Management Journal, 41, 540-555.

Wiggins, J. S. (1996). The five-factor model of personality: Theoretical perspectives. New York: Guilford.

Wrzesniewski, A., \& Dutton, J. E. (2001). Crafting a job: Revisioning employees as active crafters of their work. Academy of Management Review, 26, 179-201.

Zellmer-Bruhn, M., \& Gibson, C. B. (2006). Team strategic context: Implications for process and performance. Academy of Management Journal, 49, 501-518. 